Accordingly, he stressed the importance of insisting that the general account given in this way should be intelligible to a sufficient number of persons. Sir William also queried whether it is necessary that the Transactions and Proceedings of the Royal Society should contain as much as they do at present. When a new departure in experiment or theory is made and a new fact discovered or a new co-relation, it is right that a careful and complete explanation should be given, and if it is not too long, it is excellent that it should appear in the Proceedings. If, however, the novelty leads, as it often does, to a steady output of observation, extension, confirmation and illustration, many figures and bulky tables, complete publication to the world might become unnecessary. The scientific world requires a general account of progress made, so that its bearing may be clear. The Proceedings should accordingly contain papers of original discovery or fresh departure, but as regards continuation papers, as they may be called, properly written summaries should be enough.

\section{Co-operation in Research}

INTERNATIONAL co-operation in scientific research was also discussed in appreciative terms by Sir William Bragg, and he referred to a letter received from Dr. Bosch, president of the Kaiser Wilhelm Gesellschaft, inviting the co-operation of the Royal Society in some scientific enterprise which would advance science and at the same time promote understanding and good will, in which an exchange of visits between representatives of the Kaiser Wilhelm Gesellschaft and the Royal Society was suggested.

\section{National Registration for Man-Power}

IN the House of Commons, on December 1, Sir John Anderson, Lord Privy Seal, outlined the Government's scheme for organizing the national resources in the service of the State. The plan involves : an immediate voluntary register of manand woman-power throughout the kingdom; the publication of a handbook written in simple language as a guide to be sent to every household; a coordinated campaign of recruiting for the Services; further development of training facilities for new volunteers; making preparations for compiling in the minimum length of time a universal register under compulsory powers in the event of war. The scheme received general approval from the House. Though the time is not propitious for considering the scheme from the particular point of view of the scientific worker (further details must be known before this can be done), it is gratifying to think that embodied in the scheme is the possibility of the man of science being given the opportunity to give the State of his best (see NATURE of October 15), that is, not as a "military subordinate", but in a position where he has "a chance to use his imagination and knowledge co-ordinated with that of his fellow scientific workers and technicians, to criticize and direct, in so far as he is competent, the character of operations". Thus, and only thus, can science be expected to contribute its full share to Sir John's scheme for ensuring that our man-power and woman- power are organized in the most effective and practical way for the voluntary service of the State.

A FULL list is also to be prepared of all the key occupations which would become so essential to the nation in mobilizing for defence. In addition, special arrangements are being made for the compilation of separate registers of persons possessing exceptional professional or technical qualifications. Many of the scientific and technical institutions, we understand, have already taken steps to compile such registers, and these will be available to the Government when required. These registers, together with the records already available of men included in the special list of vital occupations, will constitute the National Voluntary Register. In the last War, many specially qualified men, including men of science, were engaged in the Services at posts which could have been just as ably, if not even more ably, filled by men with less specialized training. The National Voluntary Register will go far in preventing such a waste of man-power in the event of another war. The Government's action in building up its scheme on a voluntary basis rather than resorting to compulsion, at any rate during peace time, follows true democratic principles and is therefore commendable. Any doubts over this point of view should be allayed by Sir John's statement that these precautionary steps taken now will make it possible to compile a compulsory register within three weeks if necessary. In the event of war, of course, it would be necessary to survey and marshal our resources as a whole. The voluntary register would not then be enough, and it would become necessary to compile a universal register under compulsion. To be effective, however, such a register must be up to date, and this condition can be satisfied only if it is compiled at the time when the occasion for its use arises.

\section{Indian Cultural Studies}

IN the discussion which followed Mr. Barger's lecture at the Royal Society of Arts on November 30 (see p. 1046) interest in the future of the India Museum at South Kensington and the position of Indian studies in Great Britain will appear to have eclipsed the claims to attention of the lecturer's pioneer archæological work in Swat and Afghanistan. The importance of the question raised in his concluding remarks will be accepted in palliation. The anomalies and obstruction to development arising from the lack of cohesion and co-operation among the eight or ten organizations in London associated with Indian studies were characterized with wit and acumen by Mr. F. J. Richards, and echoed by each subsequent speaker in the discussion; while these criticisms were endorsed by Sir Richard Winstedt, who described briefly such steps, inadequate as they admittedly are, as it has been possible to take to meet these deficiencies in some measure by the provision of lectures in Indian art and archæology at the School of Oriental Studies, an institution, which, it is to be noted, already has wide commitments in other directions. On one point, which for some time past has been regarded with dismay among those 